\title{
会頭演説
}

\section{内科学のあり方 (抄録)}

\section{東京医科齿科大学第二内科 武内重五郎}

科学技術の進展に伴い，医学は著しい進歩を遂げた。 その結果, 内科学の専門化が強力に進及, 細分化の傾 向が窺われ，新しい時代に即した「内科学のあり方」 が問われている。しかし，内科学の一分野のみに精通 し, 他の領域を知らないのでは, 内科学の使命を完全 に果すことはできないまた最新の診断機器による データのみにたよつて, 病歴や現症による情報を軽視 すれば，正しい診断を基盤とした適正な治療を行らこ とはできないであろう，そこで，多年内科学の研究・ 診療・教育に従事してきた経験をむとに“内科学のあ り方にていて私見を述べてみたい。

\section{1. 内科診断学のあり方}

医学の発展とともに内科診断学の内容や教育実習に も変遷が認められる. 拙著, 内科診断学飞招いても, 1966年の初版以来数回の改訂を重ねてきた，1976年の 改訂ではproblem oriented systemによる診療記録法 を導入し，1984年の改訂では，全身的症状，系統的レ ビューを合め全身を統観する "physical diagnosis”の 重要性を再強調した。

内科診断学の基本は，病歴のとり方と現在の観察拧 よびその記録法を徹底的に訓練することである。しか し，優れた診断装置の開発により，若い医師は検査結 果の収集に専念し，患者の直接情報である病歴と現症 を軽視する傾向にある。正しく修得された， -physical diagnosis"にもとづいて病歴と現症から得られた情報 および臨床検査から得られた情報を総合して考学られ る疾患を抽出し，詳細な鑑別診断を行つてはじめて正 しい診断に到達するのである。すなわち，究極の目標 は, 内科診断学の基本を修得し，正しい診断への思孝 過程を学ぶことである.

\section{2.内科学のあり方}

内科学の本質について，上田は，「内科学は，疾病の 本態と病因を解明し，疾病を診断し適切な治療を行い, 速やかに疾病を治すことを目的とする基幹臨床医学で ある、内科学は医の本道であり，広い視野に立つ医学 であり，臨床科学である」と定義している．すなわち， 内科学は，医学全般にわたる広い知識をもとに，病因 の追求，正しい診断，適正な治療，を実践する医学で
あり，臨床医学の一分科に留まらず，各専門分野を総 合する基幹臨床医学でなければならない。

\section{1) physical diagnosis $の$ 重要性}

近年, 診断機器や検査法の進歩により診断精度は著 しく向上し，従来診断が困難であつた疾患です生前診 断が可能となつた。しかも，臨床検査は，単に診断確 定に寄与するだけでなく, 形態学的・生理学的変化や 病態の推移を知るにもきわめて有用である。しかし， 臨床検査の有用性みを重視し, 病歴の聴取や現症の観 察を怠るならば，内科医の姿勢として大きな誤りであ る. 患者の精神的・身体的苦痛を理解し，全身的な病 態を正確に把握するには, physical diagnosisが不可欠 である。また，病歴や現症から得られた知見を基礎と して診療を行觉ば，不必要な検査を行うこともなく， 患者の精神的・肉体的・経済的な無用の負担を避ける ことができる。

\section{2）全身の統観と臨床診断}

最新の診断機器と技術を用いた診断法は, 形態学的 あるいは機能的診断に対し優れた精度を示している。 しかし，これらの機器による診断は，検索対象が特定 の藏器に限局するため, 全身性病変, 合併病変, ある いは検索胹器以外の病変などを見落すことが少なくな い。この見落しを少なくするには, physical diagnosis 㧊よび全身を統観する系統的レビューが不可欠である.

\section{3）正しい診断に基つく適正な治療}

治療の本質は, 諴意をもつて患者の健康回復にあた り，生体に備わつている自然治瘜機転を助長すること である. Hippocrates医筬にもあるよ5に，患者の要望 を充分理解し，患者の立場にたつて治療することであ る. 近年, 薬物療法だけでなく，血液透析，心蔵ぺー シング．血浆交換など各種の優れた治療法が開発され ているか゚, 患者の病態を診てあらゆる角度から検討し， 最適の治療法を選ぶべきである。いずれの場合も，適 正の治療は正しい診断を基礎とする。

以上のごとく，内科診療の要諦は正しい猃断とそれ に基づく適正な治療であるが，その基本となるのは "physical diagnosis" と全身の統観であることを強調 したい. 